\title{
Letter to the editor regarding European Headache Federation guideline on the use of monoclonal antibodies acting on the calcitonin gene related peptide or its receptor for migraine prevention
}

\author{
Russell Nichols ${ }^{*}$ (D), Vladimir Skljarevski, Grazia Dell'Agnello, Hans-Peter Hundemer and Sheena K. Aurora
}

To the Editor,

We were excited to see the online publication of the European Headache Federation guideline on the use of monoclonal antibodies acting on the calcitonin gene related peptide or its receptor for migraine prevention [1]. These guidelines provide timely information for clinicians, payers, and ultimately patients in the preventive treatment of migraine and including all available and pertinent information is crucial.

While reviewing the guidelines, we noticed that EVOLVE-2, one of the galcanezumab phase 3 studies in episodic migraine, was completely omitted. Because of this, all data from this study were not considered and associated levels of certainty were downgraded throughout the publication. The guidelines reference that there was a study called EVOLVE-2, however; the reference associated with EVOLVE-2 by Skljarevski et al. [2] is a phase 2 dose finding study and the data points in Table 1 correspond to that study. Skljarevski was also the primary author for the EVOLVE-2 publication in 2018 [3] and we believe this may have led to the error. Both EVOLVE-1 and EVOLVE-2 should be accounted for in the guidelines.

EVOLVE-1 and EVOLVE-2 were identically designed phase 3 studies and 26\% of the patients in EVOLVE-2 were from Europe. Because there were similar/consistent endpoint results between the two, we believe that multiple sections in the guidelines need to be updated. Of note, the "certainty of the evidence (GRADE)" levels in multiple tables appear to have been downgraded since only 1 phase 3 study in episodic migraine for galcanezumab was noted. We believe that all levels of evidence

\footnotetext{
*Correspondence: rnichols@lilly.com

Eli Lilly and Company, and/or one of its subsidiaries, Indianapolis, IN, USA
}

and associated data for galcanezumab in episodic migraine within the article should be reviewed and updated based on the inclusion of EVOLVE-2 as a phase 3 study.

We acknowledge and thank the consensus panel and all involved in the creation of the guidelines for their countless hours and hard work. However, with this error and omission, we believe that the guidelines need to be updated to ensure an accurate and fair representation of the data.

\section{Acknowledgements Not Applicable.}

Funding

Not Applicable.

Availability of data and materials

EVOLVE-2 publication is available online at https://journals.sagepub.com/doi/ abs/10.1177/0333102418779543

\section{Authors' contributions}

All authors (RN, VS, GD, HH, and SA) participated in the conception of the letter and were major contributors for the drafting of the manuscript. All authors read and approved the final letter.

Ethics approval and consent to participate

The study protocols were reviewed and approved by the appropriate institutional review board for each of the study sites. The studies were conducted according to Good Clinical Practice and the Declaration of Helsinki guidelines. Patients provided written informed consent before undergoing study procedures.

\section{Consent for publication}

Not applicable.

\section{Competing interests}

All Authors (RN, VS, GD, HH, and SK) are all employees of Eli Lilly and Company and/or one of its subsidiaries, Indianapolis, IN, USA.

\section{Publisher's Note}

Springer Nature remains neutral with regard to jurisdictional claims in published maps and institutional affiliations. 
Received: 11 February 2019 Accepted: 20 February 2019

Published online: 01 March 2019

\section{References}

1. Sacco S, Bendtsen L, Ashina M et al (2019) European headache federation guideline on the use of monoclonal antibodies acting on the calcitonin gene related peptide or its receptor for migraine prevention. In: The journal of headache and pain. https://doi.org/10.1186/s10194-018-0955-y Accessed 18 Jan 2019

2. Skljarevski V, Oakes TM, Zhang Q, Ferguson MB, Martinez J, Camporeale A, Johnson KW, Shan Q, Carter J, Schacht A, Goadsby PJ, Dodick DW (2018) Effect of different doses of galcanezumab vs placebo for episodic migraine prevention: a randomized clinical trial. JAMA Neurol 75:187-193

3. Skljarevski V, Matharu M, Millen BA, Ossipov MH, Kim BK, Yang JY (2018) Efficacy and safety of galcanezumab for the prevention of episodic migraine: results of the EVOLVE-2 phase 3 randomized controlled clinical trial. Cephalalgia. 38:1442-1454

Ready to submit your research? Choose BMC and benefit from:

- fast, convenient online submission

- thorough peer review by experienced researchers in your field

- rapid publication on acceptance

- support for research data, including large and complex data types

- gold Open Access which fosters wider collaboration and increased citations

- maximum visibility for your research: over $100 \mathrm{M}$ website views per year

At BMC, research is always in progress.

Learn more biomedcentral.com/submissions 